\title{
Effect of Microwave Radiation on Shelf Life of Barfi
}

\author{
Rakesh Kumar $^{1 *}$, Binita Rani ${ }^{2}$, K. Dalmia ${ }^{3}$ and B.K. Singh ${ }^{4}$ \\ ${ }^{1}$ Department of Dairy Microbiology, Faculty of Dairy Technology, SGIDT, \\ Jagdeo Path, Patna, India \\ ${ }^{2}$ Dairy Chemistry, Faculty of Dairy Technology, SGIDT, Jagdeo Path, Patna, India \\ ${ }^{3}$ (Dairy Technology), Faculty of Dairy Technology, SGIDT, Jagdeo Path, Patna, India \\ ${ }^{4} \mathrm{SMS}$ (Home Science), KVK, Arwal Bihar, India \\ *Corresponding author
}

\begin{tabular}{|l|}
\hline Key w or d s \\
Microwave, Shelf- \\
life, Burfi \\
\hline Article Info \\
\hline $\begin{array}{l}\text { Accepted: } \\
\text { 04 January } 2018 \\
\text { Available Online: } \\
\text { 10 February } 2018\end{array}$ \\
\hline
\end{tabular}

\section{A B S T R A C T}

Attempts were made to enhance the shelf life of Burfi by microwave irradiation. Standard Plate Count; Coliform Count; Yeast and Mold Count; Proteolytic Count; Acid Producers Count; Staphylococcus Count and Sensory evaluation on a nine point Hedonic Scale of each product i.e. treated and untreated products stored at ambient condition $\left(30^{\circ} \mathrm{C}\right)$ and at refrigerated condition $\left(5-7^{\circ} \mathrm{C}\right)$ was done at 0 day, $2^{\text {nd }}$ day, $5^{\text {th }}$ day, $7^{\text {th }}$ day and onward till they were acceptable based on organoleptic test and consumer acceptance. The shelf life of Burfi was extended by 19 days at room temperature and 28 days at refrigeration temperature. Use of microwave radiation of Burfi is suggested to enhance the shelf life of the product.

\section{Introduction}

From very early time the simplest way to enhance the keeping quality of milk is boiling. Many thermal processes i.e. pasteurization, sterilization and UHT have gained a lot of popularity. However, many drawbacks are also related to this process of heat treatment viz. degradation of flavour and colour, nutrients, etc. Therefore alternative and safest method was searched throughout the world for any possible physical method. Present study was conducted to analyze the effect of microwave radiation on the shelf-life of Burfi. Burfi is a khoa based sweet popular throughout the Country. The presence of $E$. coli in almost all the samples of raw milk samples and other milk products like mawa/khoa, dahi cheese etc. have been reported (Haq et al., 1995 and Soomoro et al., 2002). Many studies carried out in India showed a very high contamination level besides the presence of pathogenic microorganisms such as Staphylococcus sp, Bacillus etc. (Gill et al., 1994; Mandokhot and Garg., 1986). Staphylococcus sp. is most 
frequently occurring organism in sweet based milk products such as khoa, rabri, gulabjamun etc. (Grewal and Tiwari, 1990; Hamama and Tatini, 1991). Millions of people are affected by food borne illness resulting from ingestion of toxin produced by food associated Staphylococcus. Microwave treatment is an intense thermal process, which is now widely used to extend the shelf life of various food products. It is well established that the microflora of liquid milk could be reduced by microwave treatment (Anon, 1989). Nonthermal effects were demonstrated in the early work of Fleming (1944). However, Olsen et al., (1966) was the first person who postulated the non-thermal effects of microwave heating. It has also been observed that in pasteurized milk with microwave, microbial population was lower than untreated milk and has longer shelf life. A number of studies have reported successful microwave pasteurization of milk (Hamid et al., 1969; Knutson et al., 1988). Villamiel et al., (1996) concluded that continuous microwave processing might be an efficient and mild method for the pasteurization of milk. They also concluded that shelf life of microwave treated milk was longer than that of milk heated in plate heat exchanger. Kindle, et al., (1996) reported that colony counts of all microorganisms were significantly decreased by microwave heating. However, industrial microwave processing of food did not develop rapidly due to lack of information on product safety and quality (Mudgett, 1986). A microwave oven works by passing non ionizing microwave radiation through the food. Microwave radiation is between common radio and infrared frequencies. The other major mechanism of heating with microwaves is through the polarization of ions as a result of the back and forth movement of the ionic molecules trying to align themselves with the oscillating electric field (Oliveira and Franca, 2002). Keeping in view of the above said information this study was planned and conducted to examine the effect of microwave treatment on different attributes responsible for improving shelf life of a very popular sweet of east India i.e. Burfi.

\section{Materials and Methods}

Samples of indigenous milk product Burfi were procured under aseptic conditions from the local market. All the products were separately packed in polypropylene pouches ( $75 \mu$ thickness and dimension 4 "X $\left.33^{\prime \prime}\right)$ aseptically, as suggested by Mathur et al., (1992). Two container of each sample were microwave treated and other two were kept as control. Burfi were treated at power level 40 (i.e. $400 \mathrm{w}$ ) for $7 \mathrm{sec}$. Power level and time combination was chosen based on their effect on taste, body and texture. The treated samples were kept under refrigerated condition $\left(5^{\circ} \mathrm{C}\right)$ and under ambient temperature $\left(30^{\circ} \mathrm{C}\right)$. Standard Plate Count, Coliform Count, Yeast and Mold Count according to the methods of BIS (1960); Proteolytic Count (according to the methods of Harrigan and McCance, 1976), Acid Producers Count (ISI: SP: 18); Staphylococcus Count (Chapman, 1946) and Sensory evaluation on a nine point Hedonic Scale was done for each product i.e. treated and untreated products stored at ambient condition and at refrigerated condition at 0 day, $2^{\text {nd }}$ day, $5^{\text {th }}$ day, $7^{\text {th }}$ day and onward till they were acceptable based on organoleptic test and consumer acceptance.

\section{Results and Discussion}

Effect of microwave treatment on the microbiological quality of indigenous milk products

\section{Effect on standard plate count}

In general the total plate count decreased due to microwave treatment and increased both in 
treated and untreated sample during storage (Table 1). The total plate count in fresh burfi sample was $17 \times 10^{4} \mathrm{cfu} / \mathrm{gm}$, respectively. It was observed that after microwave treatment the average reduction in total plate count was about $41 \%$ in burfi samples.

\section{Effect on coliform count}

Growth of coliform was also affected by microwave treatment. The coliform count in burfi was $140 \mathrm{cfu} / \mathrm{gm}$. Reduction in coliform count by microwave treatment was $57 \%$ in burfi. However, Fujikawa et al., (1992) reported the destruction of $E$. coli and $S$. aureus by the same microwave treatment.

\section{Effect on yeast and mold count}

There was no significant change in yeast and mold count as compared to other microbial count due to microwave treatment of Burfi. Yeast and mold count of burfi before treatment was $12 \times 10^{2} \mathrm{cfu} / \mathrm{gm}$ and after irradiation, the percent reduction in yeast and mold count was $33 \%$ in burfi.

Similar results were observed by Culkin and Fung (1975) who reported that microwave heating at $2450 \mathrm{MHz}$ caused little or no destruction of Aspergillus, Penicillium, Rhizopus etc. in foods.

\section{Effect on proteolytic count}

The proteolytic count was lower in microwave treated sample than in untreated sample. It was observed that the proteolytic count $21 \times 10^{2}$ $\mathrm{cfu} / \mathrm{gm}$. It was observed that reduction rate of proteolytic bacteria due to microwave treatment was $57 \%$ in burfi.

\section{Effect on acid producers count}

Acid producers count also reduced due to microwave treatment. In case of burfi $54.5 \%$ reduction of acid producers count was observed (Table 2).

\section{Effect on Staphylococcus count}

No Staphylococcus was detected in fresh burfi. After microwave treatment Staphylococcus counts in burfi.

According to Odani (1995) observed that the pasteurization time for killing of Staphylococcus aureus was approximately $50^{\circ} \mathrm{C}$. He suggested that the mechanism of killing of bacteria depend not only on temperature but also on other effects of microwave irradiation.

\section{Sensory evaluation}

The sensory score for flavour, colour, consistency and appearance of microwave treated burfi was observed to be same as compared to untreated products.

Effect of microwave treatment on the microbiological quality of Burfi during storage

\section{Effect on standard plate count}

Fresh burfi having $17 \times 10^{3} \mathrm{cfu} / \mathrm{gm}$, after 12 days of storage at room temperature $\left(34^{\circ} \mathrm{C}\right)$ it spoiled and that time SPC count increased to $83 \times 10^{4} \mathrm{cfu} / \mathrm{gm}$.

When the samples were kept under refrigerated condition, burfi spoiled after 23 days and count rose to $95 \times 10^{4} \mathrm{cfu} / \mathrm{gm}$.

Treated burfi initially having a plate count of $10 \times 10^{3} \mathrm{cfu} / \mathrm{gm}$ spoiled within 19 days when kept under ambient condition (SPC rose to 98 $\mathrm{X} 10^{3} \mathrm{cfu} / \mathrm{gm}$ ) and spoiled after 28 days when stored in refrigerated condition (SPC increased to $\left.92 \times 10^{3} \mathrm{cfu} / \mathrm{gm}\right)$. Similar results were observed by Kindle et al., (1996). 
Table.1 Effect of microwave treatment on Burfi

\begin{tabular}{|l|l|c|c|c|}
\hline Sr. No. & Parameter & Before $(\mathrm{cfu} / \mathrm{g})$ & After $(\mathrm{cfu} / \mathrm{g})$ & Reduction (\%) \\
\hline 1. & Standard Plate Count & 17,000 & 10,000 & 41.1 \\
\hline 2. & Coliform count & 140 & 60 & 57.1 \\
\hline 3. & Yeast and Mold Count & 1200 & 800 & 33.3 \\
\hline 4. & Proteolytic Count & 2100 & 900 & 57.1 \\
\hline 5. & Acid producers count & 220 & 100 & 54.5 \\
\hline 6. & Staphylococcus count & Nil & Nil & -- \\
\hline
\end{tabular}

Table.2 Effect of microwave treatment on Burfi during storage

\begin{tabular}{|c|c|c|c|}
\hline \multirow[t]{2}{*}{ Parameter } & \multirow[t]{2}{*}{ Sample } & \multicolumn{2}{|r|}{ Burfi } \\
\hline & & Count at 0 day & Count at the day of spoilage \\
\hline \multirow{4}{*}{$S P C$} & Untreated (at room temp.) & 17000 & 83000@12day _ \\
\hline & Untreated (at refrigeration temp.) & 17000 & 95000@23day \\
\hline & Treated (at room temp.) & 10000 & 98000@19day \\
\hline & Treated (at refrigeration temp.) & 10000 & 92000@28day \\
\hline \multirow{4}{*}{ Coliform } & Untreated (at room temp.) & 140 & 470@12day \\
\hline & Untreated (at refrigeration temp.) & 140 & 550@23day \\
\hline & Treated (at room temp.) & 60 & 560@19day \\
\hline & Treated (at refrigeration temp.) & 60 & 600@28day \\
\hline \multirow{4}{*}{$\begin{array}{l}\text { Yeast \& mold } \\
\text { count }\end{array}$} & Untreated (at room temp.) & 1200 & 9900@12day \\
\hline & Untreated (at refrigeration temp.) & 1100 & 9800@23day \\
\hline & Treated (at room temp.) & 800 & 9700@19day \\
\hline & Treated (at refrigeration temp.) & 800 & 10200@28day \\
\hline \multirow{4}{*}{$\begin{array}{l}\text { Proteolytic } \\
\text { count }\end{array}$} & Untreated (at room temp.) & 2100 & 5900@12day \\
\hline & Untreated (at refrigeration temp.) & 2100 & 8100@23day \\
\hline & Treated (at room temp.) & 900 & 6100@19day \\
\hline & Treated (at refrigeration temp.) & 900 & 8600@28day \\
\hline \multirow{4}{*}{$\begin{array}{l}\text { Acid Producers } \\
\text { count }\end{array}$} & Untreated (at room temp.) & 220 & 1100@12day \\
\hline & Untreated (at refrigeration temp.) & 220 & 1020@23day \\
\hline & Treated (at room temp.) & 100 & 1050@19day \\
\hline & Treated (at refrigeration temp.) & 100 & 980@28day \\
\hline \multirow{4}{*}{$\begin{array}{l}\text { Staphylococcus } \\
\text { count }\end{array}$} & Untreated (at room temp.) & 0 & 0@12day \\
\hline & Untreated (at refrigeration temp.) & 0 & 0@23day \\
\hline & Treated (at room temp.) & 0 & 0@19day \\
\hline & Treated (at refrigeration temp.) & 0 & 0@28day \\
\hline
\end{tabular}




\section{Effect of coliform count}

In fresh burfi coliform count was 14X 10 $\mathrm{cfu} / \mathrm{gm}$. After microwave treatment the count reduced to $6 \mathrm{X} 10 \mathrm{cfu} / \mathrm{gm}$. Untreated sample spoiled after 12 days of storage at room temperature when count increased to $47 \mathrm{X} 10$ cfu/gm and spoiled after 23 days of storage under refrigerated condition when count rose to $55 \mathrm{X} 10 \mathrm{cfu} / \mathrm{gm}$. Treated burfi sample was spoiled after 23 days under ambient condition and count increase to $56 \mathrm{X} 10 \mathrm{cfu} / \mathrm{gm}$ and spoiled within 28 days under refrigerated condition when count increase to $60 \times 10$ $\mathrm{cfu} / \mathrm{gm}$.

\section{Effect of yeast and mold count}

Fresh burfi, having yeast and mold count 12 $\mathrm{X} 10^{2} \mathrm{cfu} / \mathrm{gm}$ was spoiled after 12 days of storage at room temperature (count increased to $99 \times 10^{2} \mathrm{cfu} / \mathrm{gm}$ ) and spoiled by 23 days of storage under refrigerated condition (count increased to $98 \times 10^{2} \mathrm{cfu} / \mathrm{gm}$ ). Treated burfi sample (initially yeast and mold count was 8 X $10^{2} \mathrm{cfu} / \mathrm{gm}$ ) damaged by 19 days of storage at room temperature (yeast and mold count $97 \times 10^{2} \mathrm{cfu} / \mathrm{gm}$ ) and by 28 days of storage under refrigerated condition (yeast and mold count $\left.102 \times 10^{2} \mathrm{cfu} / \mathrm{gm}\right)$. Culkin and Fung (1975) reported microwave treatment at $2450 \mathrm{MHz}$ caused greater destruction of Aspergillus, Penicillium, Rhizopus etc. in foods than heating alone.

\section{Effect on proteolytic count}

In case burfi fresh sample (proteolytic count $\left.21 \times 10^{2} \mathrm{cfu} / \mathrm{gm}\right)$ spoiled by 12 days when stored at room temperature (proteolytic count rose to $59 \times 10^{2} \mathrm{cfu} / \mathrm{gm}$ ) and spoiled by 23 days when stored under refrigerated condition (proteolytic count rose to $81 \times 10^{2} \mathrm{cfu} / \mathrm{gm}$ ). In case of treated sample (proteolytic count $9 \mathrm{X}$ $10^{2} \mathrm{cfu} / \mathrm{gm}$ ) spoiled by 9 days when stored at room temperature (proteolytic count rose to $\left.62 \times 10^{2} \mathrm{cfu} / \mathrm{gm}\right)$ and spoiled by 28 days when stored under refrigerated condition (proteolytic count rose to $91 \times 10^{2} \mathrm{cfu} / \mathrm{gm}$ ).

\section{Effect on acid producers count}

Number of acid producer's colonies in fresh burfi was $22 \times 10^{2} \mathrm{cfu} / \mathrm{gm}$ and increased to 61 $\mathrm{X} 10^{2} \mathrm{cfu} / \mathrm{gm}$ after 9days when it stored at room temperature and to $92 \times 10^{2} \mathrm{cfu} / \mathrm{gm}$ after 23 days under refrigerated condition. The count at microwave treated $(600 \mathrm{~W}$ for $30 \mathrm{sec}$.) was $10 \times 10^{2} \mathrm{cfu} / \mathrm{gm}$ and increased to $59 \times 10^{2} \mathrm{cfu} / \mathrm{gm}$ after 12 days when it stored at room temperature and to $81 \times 10^{2} \mathrm{cfu} / \mathrm{gm}$ after 28 days under refrigerated condition. Kozempel (1998) observed similar result.

\section{Effect on Staphylococcus count}

Microwave treatment (600W for 30sec) had a significant inhibitory effect on survival of Staphylococcus spp. in burfi sample Staphylococcus spp was absent in $1^{\text {st }}$ dilution. Similar result was observed by Hammad (1998).

\section{Sensory evaluation}

The sensory score for flavour, colour, consistency and appearance of microwave treated burfi were observed to be same as compared to untreated products. On the basis of organoleptic evaluation it was observed that the quality of burfi before and after treatment were almost same. During storage the overall acceptability of control sample was decreased to a greater extend than those of microwave treated sample. Microwave treated samples of burfi stored under refrigerated condition was evaluated for 28 days, whereas untreated Burfi stored under refrigerated condition was evaluated for 23 days. During storage colour and appearance, smell of both the product was more affected than body and texture. Colour and appearance 
more quickly deteriorated due to mold growth and taste and flavour deteriorated due to acid producer's bacterial growth. Mathur et al., (1992) observed similar results in paneer.

Microwave treated Burfi samples were evaluated for 19 days at room temperature whereas under refrigerated condition it was evaluated for 28 days. Control sample of untreated Burfi was evaluated for 12 days at room temperature and 23 days at at refrigeration temp respectively. During storage, colour and appearance, smell of Burfi was more affected than body and texture. Colour and appearance more quickly deteriorated due to mold growth and taste and flavour deteriorated due to acid producers' bacterial growth. It has been reported that microwave treatment of Burfi up to $115^{\circ} \mathrm{C}$ for $5 \mathrm{~m}$ did affect the body and texture and flavour attributes of the product and increase the shelf life and can be effectively utilized for fulfilling the local rural market demand.

\section{Acknowledgement}

We acknowledge the moral support and help from Sanjay Gandhi Institute of Dairy Technology, Bihar Agricultural University, Sabour, Bhagalpur, Bihar, India

\section{References}

Anon, 1989. Microwave food processing, Food Technology, 43(1): 17

BIS (ISI) 1960. Bureau of Indian Standard. Manak Bhawan, New Delhi; IS: 1449: Part.I Method of test for examination of dairy products.

Chapman, G. H. 1946. A single culture medium for selective isolation of plasma- coagulating Staphylococci and for improved testing of chromogenesis, plasma coagulation, mannitol fermentation, and the Stone reaction. $J$. Bacterial. 51: 409-410.
Culkin, K. A. and Fung, D. Y. C. 1975. Destruction of Escherichia coli and Salmonella typhimurium in microwave cooked soup. J. Milk Food Technol., 38, 8-15.

Fleming, H. 1944. Effect of high frequency field on microorganisms. Electron. Eng. 63(1): 18-21

Fujikawa, H., Ushioda, H and Kudo Y. 1992. Kinetics of Escherichia coli destruction by microwave irradiation. Applied and Environmental Microbiology. 58(3): 920-924.

Gill, J.P.S, Joshi, D.V. and Kwatra M.S. 1994. Qualitative bacteriological survey of milk and milk products with special reference to Staphylococcus aureus. Ind J of Dairy Sci. 47: 680

Grewal, J.S. and Tiwari, I. R. 1990. Microbiological quality of rasmalai. $J$. food sci. Technol. 27:178-179.

Hamama, A. and Tatini S.R. 1991. Enterotoxigenicity of $S$. aureus isolates from Moroccan raw milk and traditional dairy products. Microbiol ali and Nutr. 9:263-267

Hamid, M. A. K., Boulanger, R J., Tong, S. C. GaUop, R A. and Pereira, R. R. 1969. Microwave pasteurization of raw milk, J. Microwave Power. 4(4):272275.

Hammad, A.A.I. 1998. Efficiency of domestic microwave oven in eliminating pathogenic bacteria from fresh foods and milks. Asian Journal of Agricultural Sciences, 29(3): 19-32.

Haq, I, Mahmod, F., Qadeer, M. A. Mukhtar H. and Iqbal, 1995. A microbial examination of khoa. Biologia, 44: 127132.

Harrigan, W. F. and McCance, M.E. 1976. Laboratory Methods in food and Dairy Microbiology. Academic Press, London, Pp. 358.

ISI: SP: 18 Handbook of Food Analysis (Part XI). Dairy products. Indian Standard 
Institution. Manak Bhawan, New Delhi, 1981.

Kindle, G., Busse, A., Kampa, D., MeyerKoning, U. and Daschner, F.D. 1996. Killing activity of microwave in milk. Journal of Hospital Infection, 33(4):279 -278 .

Knutson, K. M. Marth, E. H. and Wagner, M. K. 1988. Use of microwave ovens to pasteurize milk. J. Food Prot. 51(9):715-719.

Kozempel, M.F; Annous, B.A., Cook, R.D; Schullen, O.J. and Whiting, R.C. 1998. Inactivation of microorganisms with microwaves at reduced temperature. Journal of Food Protection, 61(5): 582585

Mandokhot W. and Garg S. R. 1986. Market quality of khoa, burfi and pera: A critical Review. J. Food Sci. Technol., 22:299.

Mathur, B.N., Vijay Kumar; Thompkinson, D.K. and Goyal, G.K. 1992. Preservation of indigenous milk products employing microwave processing. Annual Report, p. 96, NDRI, Karnal.

Mudgett, R. E., 1989. Microwave food processing: A Scientific Status
Summary by the IFT Expert Panel on Food Safety and Nutrition. Food Technology 43(1): 117-126.

Odani, S., Abe, T. and Mitsuma, T. 1995. Pasteurisation of food by microwave irradiation. Sokuhin Eiscigakuzasshi Journal of the Food Hygiene Society of Japan. 36(4): 477-481.

Oliveira, M.E.C. and Franca, A S. 2002. Microwave heating of foodstuff. $J$. Food Eng. 53: 347-359.

Olsen, C. M., Drake, C. L. and Bunch, S. L. 1966. Sorne biological effects of microwave energy. J. Microwave Power $1(2): 45-51$

Soomoro A.H. Arain M.A., Khaskhedi M \& Bhutto B, 2002. Isolation of E.coli from raw milk and milk products in relation to public health sold under market conditions at Tandojam. Pak. J. Nutr. 1: 151-152

Villamiel, M., Lpaz-Fardino, R., Corzo, N., Martinez-Castyro, I., Olano, A., Fardin, R.L., Microwave pasteurization of milk in a continuous flow unit. Effect on cheese making properties of goat's milk. Milchwisenchaft, 52(1): 29 -32.

\section{How to cite this article:}

Rakesh Kumar, Binita Rani, K. Dalmia and Singh, B.K. 2018. Effect of Microwave Radiation on Shelf Life of Burfi. Int.J.Curr.Microbiol.App.Sci. 7(02): 193-199. doi: https://doi.org/10.20546/ijcmas.2018.702.024 